\title{
Surfactant protein $A$ in the course of respiratory distress syndrome
}

\author{
P. A. Stevens*, B.Schadow*, S.Bartholain, H.Segerer, and M.Obladen \\ Department of Neonatology, University Children's Hospital, Free University Berlin, Heubnerweg 6, 1000 Berlin, \\ Federal Republic of Germany
}

Received July 22, 1991 / Accepted after revision December 4, 1991

\begin{abstract}
Surfactant-associated protein (SP-A) was measured in tracheal aspirates of ventilated infants with $(n=$ 51) and without $(n=21)$ respiratory distress syndrome (RDS). SP-A concentrations in samples collected after birth were significantly lower in RDS than in infants ventilated for other reasons than RDS (median 0.03 vs. 1.60 $\mu \mathrm{g} / \mathrm{ml}$ ). As a biochemical test to diagnose RDS early after birth, the sensitivity of measuring SP-A in tracheal aspirates was $87 \%$ and specificity $81 \%$. SP-A content in tracheal aspirates of infants with RDS was monitored during the first 7 days of life. A significant $(P<0.001)$ increase within the first 4 days was found in those infants who survived, whereas no such change was found in those infants who died.
\end{abstract}

Key words: Respiratory distress syndrome - Surfactant protein A

\section{Introduction}

The surfactant-associated protein (SP-A) (MW 28-36000), secreted by type II alveolar cells is developmentally regulated. Its concentration in amniotic fluid increases during the third trimester of gestation parallelling the increase in surfactant phospholipids during that period $[7$, $13,23]$. Measurement of the SP-A concentration in amniotic fluid has therefore been used to assess lung maturity $[11,12,14,22]$.

After birth, an estimate of its concentration in the alveoli could help distinguish between true respiratory distress syndrome of the premature [i.e. primary surfactant deficiency, respiratory distress syndrome (RDS)] and other clinical entities, which can mimic RDS, such as connatal pneumonia, Group B-streptococcal disease, pulmonary maladaptation and shock lung [8]. Knowledge of its concentration might be useful for the understanding of lung abnormality in RDS and of lung repair after such

* The contributions of the first two authors should be considered equal

Offprint requests to: $\mathrm{P}$. A. Stevens

Abbreviations: $\mathrm{SP}-\mathrm{A}=$ surfactant-associated protein $\mathrm{A} ; \mathrm{RDS}=$ respiratory distress syndrome injury. It might also be possible to predict the course of RDS, whether the baby will recover, will develop chronic lung disease, or even die [16].

The purpose of our study was to use an enzyme-linked immunoassay (ELISA) as a biochemical tool in addition to clinical and radiological criteria for the diagnosis of RDS. We postulated that differences in the outcome from RDS are reflected in the SP-A content of tracheal aspirates in the first 7 days after birth.

\section{Patients and methods}

\section{Patients}

We studied 51 consecutive ventilated infants with RDS (RDS group) and 21 consecutive infants who were ventilated for reasons other than RDS (non-RDS group) in the same period. Reasons for ventilation in the non-RDS group included: sepsis/connatal infection $(n=7)$; wet lung disease $(n=3)$; chromosomal aberrations $(n=2)$; persistent fetal circulation $(n=1)$; meconium aspiration $(n=1)$; perinatal asphyxia $(n=2)$.

Diagnoses were made within the first $6 \mathrm{~h}$ after birth. Unless the babies had overt connatal infection, we included in the "RDS" group all babies with a clinical and roentgenological picture consistent with RDS, using the criteria of Hjalmarson [9]. Connatal infection was diagnosed if two out of the following three criteria were fulfilled: (1) positive blood cultures or swabs at birth; (2) immature to total neutrophils ratio $\geq 0.20$; (3) C-reactive protein concentration at birth $>1 \mathrm{mg} / \mathrm{dl}$. All diagnoses were made at the bedside without knowledge of the results of the tracheal aspirate studies, and for this study were not revised. Tracheal aspirates were sampled at intubation and subsequently in the 1st week of life during routine airway suctioning after instillation of $1 \mathrm{ml}$ physiological saline. In addition gastric aspirates of healthy mature infants ( $>36$ weeks of gestation) were collected at birth (normal group). Samples were frozen at $-20^{\circ} \mathrm{C}$ until assayed.

Surfactant substitution. Surfactant treatment in RDS was carried out as a clinical trial using Curosurf, a semi-natural surfactant of porcine origin, which does not contain SP-A [4]. Details of the trial are published elsewhere [21].

\section{Biochemical analysis}

Anti-human surfactant protein A antibodies (rabbit polyclonal and mouse monoclonal) and human recombinant SP-A were a gracious gift from Byk Gulden, Konstanz, Federal Republic of Germany.

ELISA. A non-competitive "sandwich" immunoassay, similar to [14], using a monoclonal anti-human SP-A antibody as the first and a polyclonal anti-human SP-A antibody as the second anti- 
body was set up. $100 \mu \mathrm{l}$ of standards and samples, diluted in $10 \mathrm{~m} M$ Tris, $150 \mathrm{~m} M \mathrm{NaCl}, 0.05 \%$ Tween 20 were applied. Standard rows ranging from $1 \mathrm{ng} / \mathrm{ml}$ to $1 \mu \mathrm{g} / \mathrm{ml}$ as well as a blank (dilution buffer) were run on each plate. Each sample was diluted 1:100 and 1: 2000 . The third antibody was a peroxidase-conjugated goat antirabbit (IgG) antibody. Optical density was read at $492 \mathrm{~nm}$.

Additional methods. For determination of total protein the BioRad Protein Assay (Bio-Rad, Richmond, $\mathrm{Ca}$ ) was used with bovine serum albumin as standard. Phospholipid content was measured using the method according to Bartlett [1] after lipid extraction [2].

Statistics. For statistical comparisons the chi-square test, the MannWhitney test for non-parametric data and Friedman's analysis of variance were used. Since the source of the sample in the normal group (gastric aspirate) was different from that of both other groups (tracheal aspirate), no comparative statistics were done using the data from the normal group. The results are included only to illustrate the normal range of values at term.

In the RDS as well as the non-RDS group the number of cases decreased with time due to patient recovery or death. Therefore, in order to compare the course of the SP-A concentrations with time in these groups with varying cell numbers, the following two techniques were applied:

1. For each individual the value at day 1 was subtracted from values at subsequent days after birth (e.g. day 2-day 1, day 3-day 1 , etc.). At each time point, the residuals in the RDS groups were then compared to those in the non-RDS group by the Mann-Whitney test with Bonferoni's adjustment for multiple comparisons applied. This procedure is subsequently called: $\Delta-\mathrm{d} 1$.

2. For each individual values at a particular time point were subtracted from the value at the next day. The resulting differences were then compared between the RDS and non-RDS groups by the Mann-Whitney test with Bonferoni's adjustment for multiple comparisons applied. This procedure is subsequently called: $\Delta-p$.

\section{Results}

\section{Validation of methods}

We have no absolutely reliable way of determining whether the tracheal samples collected reflected alveolar contents. However, as mentioned before, SP-A is produced solely by the alveolar type II cell. Our results might also be biased by a dilution factor, depending on how much saline is reaspirated with tracheal suctioning and on the contribution of extra-alveolar secretions. Calculating the SP-A to total protein ratio helped to exclude samples in which only the instilled saline was recovered. However, using this ratio did not yield more information than using SP-A concentrations alone. Chida et al. reported similar findings using surfactant protein/albumin ratios [3]. No correlation was found between the concentration of SP$\mathrm{A}$ in the sample and the volume of the sample. For the purposes of this paper, only the results from the SP-A concentration measurements are therefore presented.

The intra-assay coefficients of variation, calculated by comparing the results of 12 standard rows on one plate, were 0.16 for $1 \mathrm{ng} / \mathrm{ml}, 0.11$ for $5 \mathrm{ng} / \mathrm{ml}, 0.16$ for $10 \mathrm{ng} / \mathrm{ml}$ and 0.07 for $50 \mathrm{ng} / \mathrm{ml}$. The between-assay coefficients of variation, calculated by comparing the results of 12 standard rows on 12 plates assayed in a period of 4 months, were 0.29 for $1 \mathrm{ng} / \mathrm{ml}, 0.21$ for $5 \mathrm{ng} / \mathrm{ml}, 0.18$ for $10 \mathrm{ng} / \mathrm{ml}$ and 0.14 for $50 \mathrm{ng} / \mathrm{ml}$.

\section{Patients}

Fifty-one infants fulfilled clinical and roentgenological criteria for RDS (RDS group) and 17 infants in this group were treated with exogenous surfactant. Twenty-one infants were ventilated for reasons other than RDS (nonRDS group).

Non-RDS infants were more mature and weighed more than RDS infants. The proportion of infants treated antenatally with lung maturation-stimulating drugs was lower in the non-RDS group than in the infants with RDS (3/16 vs. 20/51).

Thirteen infants with RDS died, 4 of these within the 1st week of life. In the surfactant-treated subgroup, 2/17 infants died, both after the 1st week of life. Of the infants with RDS who had not been treated with surfactant, $11 / 34$ died ( 4 in the 1 st week of life). Of the 21 infants in the non-RDS group, 4 died, one of these within the 1 st week of life.

\section{Measurements}

As shown in Table 1, SP-A values on the 1st day of life in neonates with RDS were significantly lower than in ventilated newborns without RDS $(P<0.001)$. In Fig. 1 the distribution of the SP-A concentrations in tracheal aspirates at birth of infants with RDS and without RDS is shown.

Data from a previous study by Gerdes et al. suggested that artificial ventilaton by itself could have increased
Table 1. Biochemical analysis of the tracheal aspirate contents at birth

\begin{tabular}{|c|c|c|c|c|}
\hline & RDS & & Non-RDS & Normal \\
\hline SP-A & 0.03 & $*$ & 1.60 & 6.96 \\
\hline$(\mu \mathrm{g} / \mathrm{ml})$ & $\left(\begin{array}{ll}0 & -2.52\end{array}\right)$ & & $\left(\begin{array}{ll}0 & -42.19\end{array}\right)$ & $(0.15-98.36)$ \\
\hline $\begin{array}{l}\text { Total protein } \\
(\mathrm{mg} / \mathrm{ml})\end{array}$ & $\begin{array}{l}0.56 \\
(0.02-10.32)\end{array}$ & & $\begin{array}{l}0.89 \\
(0.07-2.34)\end{array}$ & $\begin{array}{l}3.38 \\
(1.47-5.84)\end{array}$ \\
\hline $\begin{array}{l}\text { Phospholid } \\
\text { (mg/ml) }\end{array}$ & $\begin{array}{l}0.02 \\
(0-8.13)\end{array}$ & & $\begin{array}{l}0.17 \\
\left(\begin{array}{ll}0 & -4.23)\end{array}\right.\end{array}$ & $\begin{array}{l}0.25 \\
(0.03-0.68)\end{array}$ \\
\hline $\begin{array}{l}\text { SP-A/protein ratio } \\
\quad(\mu \mathrm{g} / \mathrm{mg})\end{array}$ & $\begin{array}{l}0.1 \\
\left(\begin{array}{ll}0 & -2.03\end{array}\right)\end{array}$ & $* *$ & $\begin{array}{l}1.83 \\
\left(\begin{array}{ll}0 & -28.88\end{array}\right)\end{array}$ & $\begin{array}{l}27.43 \\
(0.1-27.94)\end{array}$ \\
\hline
\end{tabular}

$* P<0.001 ; * * P<0.002$ 


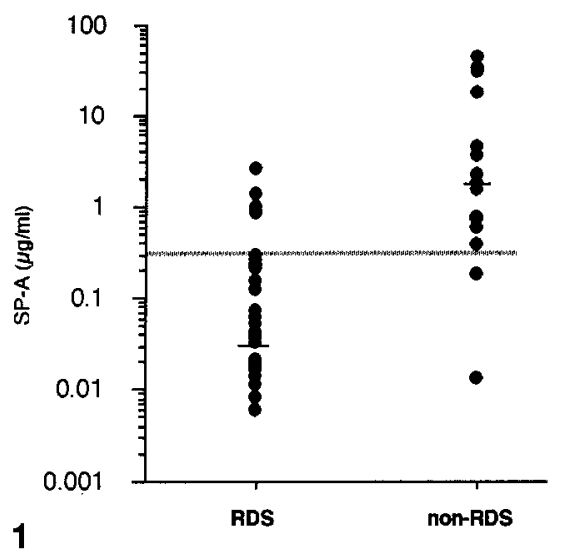

1

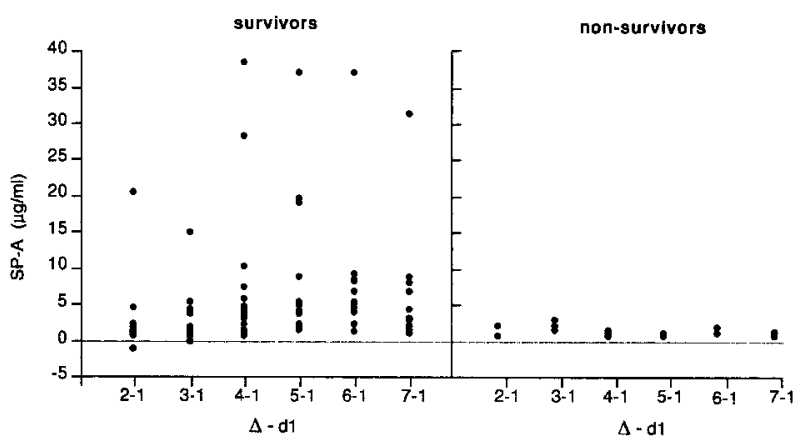

Fig. 3. Difference in SP-A values between day 1 and subsequent days in the 1st week of life in ventilated infants with RDS who survived compared to infants with RDS who died. The dotted line serves to illustrate zero difference, i.e. no change in SP-A concentrations in tracheal aspirate between a given day and day 1 (birth)

alveolar SP-A concentrations to values above those found on the 1st day of life in similar infants without artificial ventilation [6]. For this graph and the design of the diagnostic test, we therefore used only the results from samples collected immediately after birth (38 in the RDS group, 16 in the non-RDS group). We constructed a Receiver Operating Characteristics curve, and graphically determined the point at which the optimal combination of sensitivity and specificity was obtained (Fig. 2). With a cutoff value of $0.3 \mu \mathrm{g} / \mathrm{ml}$ SP-A in tracheal aspirate, 33 cases $(87 \%)$ in the RDS group were below and $5(13 \%)$ values above the cutoff point. In the non-RDS group there were $3(19 \%)$ values below and 13 values $(81 \%)$ above the cutoff point. This difference, calculated with the chi-square test with continuity correction for small numbers, was significant at $P<0.0001$.

The course of SP-A concentration in tracheal aspirates was followed during the 1st week of life. In infants who recovered from RDS there was a gradual but significant increase in SP-A concentrations during the first 4 days of life to levels similar to those in infants without RDS (Friedman's analysis of variance, $P<0.001$ ). In infants who did not survive, the SP-A concentrations stayed low - in most cases below the cutoff value - and never reached normal levels. In the non-RDS group SP-A levels varied from day to day and from patient to patient, but no trend was detectable. The infants in this group who died had SP-A levels above the cutoff point.
Fig. 1. SP-A concentrations in tracheal aspirates on the first day of life in 38 infants with RDS (RDS) compared to those in 16 ventilated infants without RDS (non-RDS). The Y-axis has a logarithmic scale. The hatched line represents the cutoff value used for diagnosis of RDS $(0.3 \mu \mathrm{g} / \mathrm{ml})$. Median values are indicated by short horizontal lines

Fig. 2. Receiver operating characteristics curve for tracheal aspirate SP-A concentrations in the diagnosis of RDS. The SP-A values $(\mu \mathrm{g} / \mathrm{ml})$ of chosen cutoff points are in parentheses

\section{Discussion}

Diagnosing RDS of prematurity and distinguishing it from other disease entities quickly and correctly is becoming an important issue, now that surfactant substitution is rapidly gaining acceptance as standard therapy for RDS. Investigators involved in the original surfactant substitution studies found that $40 \%-60 \%$ of the babies treated with surfactant for presumed primary RDS, had no RDS as defined by biochemical criteria [17].

A more accurate diagnosis of the cause of respiratory distress of the newborn might therefore help in predicting which infants will benefit from surfactant substitution.

A reliable assessment of lung maturity depends on the availability of a marker which is sufficiently specific for the aspect of lung development which is of interest. Most such clinically used tests depend on the increase with gestation in phospholipid content of amniotic fluid or gastric or tracheal aspirates at birth. In agreement with Chida et al. [3] our study shows that the concentration of pulmonary surfactant-associated protein SP-A in tracheal aspirate is another reliable indicator of lung maturity. In contrast to most tests using surfactant phospholipid component, which could be contaminated with exogenous phospholipids (e.g. cell membranes, etc.) [5, $10,20]$, the SP-A assay system is more surfactant-specific and will detect such small amounts to be clinically useful even with small samples obtained from very low birth weight infants. 
Table 2. Clinical data of the patients

\begin{tabular}{lccc}
\hline & $\begin{array}{l}\text { RDS } \\
(n=51)\end{array}$ & $\begin{array}{l}\text { non-RDS } \\
(n=21)\end{array}$ & $\begin{array}{c}\text { Normal } \\
(n=26)\end{array}$ \\
\cline { 1 - 3 } $\begin{array}{l}\text { Gestational age } \\
\quad \text { (weeks) }\end{array}$ & 29 & 36 & 40 \\
Mean birth weight & $(26-36)$ & $(25-43)$ & $(38-42)$ \\
$\quad(g)$ & $(570-2640)$ & $(700-4100)$ & $(2900-4040)$ \\
Female & 26 & 6 & 10 \\
Male & 25 & 10 & 16 \\
Umbilical artery pH & 7.29 & 7.26 & 7.29 \\
& $(6.7-7.43)$ & $(6.92-7.35)$ & $(7.18-7.37)$ \\
Antenatal drugs & 20 & 3 & 0 \\
\hline
\end{tabular}

Antenatal durgs: betamethasone or ambroxol given antenatally to stimulate lung maturation. Data are median and (minimum maximum)

As expected, babies with RDS were smaller than those in the non-RDS group, which reflects their lower median gestational age (Table 2). However, differences in gestational age and birth weight only partially explain the difference in SP-A values found. Even after matching for gestational age and/or birth weight, the non-RDS group had higher SP-A values than the RDS group (data not shown). As stated in methods, unless the babies had connatal infection, all babies which fulfilled clinical and roentgenological criteria for RDS were included in this group. Therefore, some infants which had disorders, such as pulmonary maladaptation, as defined by $\mathrm{Hjal}$ marson [9], respiratory distress secondary to perinatal shock, etc., may have been included in the RDS group. These may account for some of the high SP-A values in this group. Conversely, some of the extremely low values in the non-RDS group could be explained by the coincidence of RDS and infection.

Measurement of SP-A contents of tracheal aspirates has also broader interest as a possible parameter for monitoring wound healing in the lung. In surviving infants the increase in SP-A concentrations with time parallels resolving RDS (Fig. 3). This can be explained by several possible mechanisms. Normal lung maturation might be accelerated in premature infants after birth. Factors associated with RDS might stimulate type II cells to start producing and secreting more surfactant. Nogee et al. found that the SP-A content of alveolar lavages and lung tissue of adult rats increased in response to hyperoxia. They demonstrated that this was at least in part due to increased gene expression and protein synthesis $[18,19]$. This might be a mechanism by which the lung tries to protect itself against the effects of oxygen injury. Another possible mechanism could be an alteration in the clearance of surfactant components from the alveolous as the alveolar epithelial barrier, which is leaky in the acute phase of the disease, becomes progressively tighter with time.

The SP-A concentrations in infants with severe RDS who died, on the other hand did not increase. Similarly to the results after extracorporeal membrane oxygena- tion, as reported by Lotze et al. [15], unsuccessful weaning correlated with lack of increase in SP-A concentrations with time. These results also parallel findings from immunostaining experiments in lungs of infants dying from RDS [16].

In conclusion, measuring the SP-A content in tracheal aspirates can be used as an additional, rapid and relatively reliable tool for the diagnosis of RDS. Its measurement could also help in assessing the eventual outcome of the pulmonary disease, since the SP-A concentration increases in the 1st week of life in those infants who will recover. In those infants who died, SP-A concentrations remained low and never reached normal values. Further studies are needed to elucidate the mechanism of the increase in recovering infants.

Acknowledgements. The authors thank Mrs. Evelyn Waiß and $\mathrm{Ma}-$ rius Bartsch, MD for technical assistance. This work was supported in part by Deutsche Forschungsgemeinschaft Grant Ste 459/1-1.

\section{References}

1. Bartlett GR (1959) Phosphorus assay in column chromatography. J Biol Chem $234: 466-468$

2. Bligh EG, Dyer WJ (1959) A rapid method of total lipid extraction and purification. Can J Biochem Physiol 37:911-917

3. Chida S, Phelps D, Cordle C, Soll R, Floros J, Taeusch HW (1988) Surfactant-associated proteins in tracheal aspirates of infants with respiratory distress syndrome after surfactant therapy. Am Rev Respir Dis 137:943-947

4. Collaborative European Multicenter Study Group (1989) Surfactant replacement therapy for severe neonatal respiratory distress syndrome: an international randomized clinical trial. Pediatrics 82:683-691

5. Francoual J, Magny JF, Ropert JC, Dehan M, Leluc R (1987) Phosphatidylglycerol in tracheal aspirates for diagnosis of hyaline membrane disease. Arch Dis Child 62:193-194

6. Gerdes JS, Abbasi S, Karp K, Hull W, Whitsett JA (1990) Surfactant protein-A in bronchoalveolar lavage fluid from neonates with RDS on conventional and high-frequency oscillatory ventilation. Pediatr Pulmonol 9:166-169

7. Gikas EG, King RJ, Mescher EJ, Platzker ACG, Kitterman JA, Ballard PL, Benson BJ, Tooley WH, Tooley WH, Clements JA (1977) Radioimmunoassay of pulmonary surface-active material in the tracheal fluid of the fetal lamb. Am Rev Respir Dis 115:587-593

8. Hallman M, Arjomaa P, Mizumoto M, Akino T (1988) Surfactant proteins in the diagnosis of fetal lung maturity. 1. Predictive accuracy of the $35 \mathrm{kD}$ protein, the lecithin/ sphingomyelin ratio, and phosphatidylglycerol. Am J Obstet Gynecol 158: $531-535$

9. Hjalmarson O (1981) Epidemiology and classification of acute, neonatal respiratory disorders. Acta Paediatr Scand 70:773783

10. Kattner E, Maier R, Waiß E, Stevens P (1990) Lecithin/sphingomyelin ratio from tracheal aspirates and compliance of the respiratory system in infants with bronchopulmonary dysplasia. Lung [Suppl] : 883-890

11. Katyal SL, Amenta JS, Singh G, Silverman JA (1984) Deficient lung surfactant apoproteins in amniotic fluid with mature phospholipid profile from diabetic pregnancies. Am J Obstet Gynecol 148: 48-53

12. Katyal SL, Singh G (1983) An enzyme-linked immunoassay of surfactant apoproteins. Its application to the study of fetal lung development in the rat. Pediatr Res 17:439-443

13. King RJ, Ruch J, Gikas EG, Platzker ACG, Creasy RK (1975) Appearance of apoproteins of pulmonary surfactant in human amniotic fluid. J Appl Physiol 39:735-741 
14. Kuroki Y, Takahashi H, Fukada Y, Mikawa M, Inagawa A, Fujimito S, Akino T (1985) Two-site "simultaneous" immunoassay with monoclonal antibodies for the determination of surfactant apoproteins in human amniotic fluid. Pediatr Res 19: $1017-1020$

15. Lotze A, Whitsett JA, Kammerman JA, Ritter M, Taylor GA, Short BL (1990) Surfactant protein A concentrations in tracheal aspirate fluid from infants requiring extracorporeal membrane oxygenation. J Pediatr 116:435-440

16. deMello DE, Phelps DS, Patel G, Floros J, Lagunoff D (1989) Expression of the $35 \mathrm{kDa}$ and low molecular weight surfactantassociated proteins in the lungs of infants dying with respiratory distress syndrome. Am J Pathol 134: 1285-1293

17. Merritt TA, Hallman M (1988) Surfactant replacement. A new era with many challenges for neonatal medicine. Am J Dis Child 142:1333-1339

18. Nogee LM, Wispé JR (1988) Effects of pulmonary oxygen injury on airway content of surfactant-associated protein A. Pediatr Res 24:568-573
19. Nogee LM, Wispé JR, Clark JC, Whitsett JA (1989) Increased synthesis and mRNA of surfactant protein $\mathrm{A}$ in oxygen-exposed rats. Am J Respir Cell Mol Biol 1:119-125

20. Obladen M, Gluck L (1977) Tracheale Phospholipide beim Atemnotsyndrom des Neugeborenen. Monatsschr Kinderheilkd 125:431-433

21. Segerer H, Stevens P, Schadow B, Maier R, Kattner E, Schwarz H, Curstedt T, Robertson B, Obladen M (1991) Surfactant substitution in ventilated very low birth weight infants: factors related to response types. Pediatr Res 30:591-596

22. Shelley SA, Balis JU, Paciga JE, Knuppel RA, Ruffolo EH, Bouis PJ (1982) Surfactant "apoproteins" in human amniotic fluid: an enzyme-linked immunosorbent assay for the prenatal assessment of lung maturity. Am J Obstet Gynecol 144:224228

23. Wright JR, Clements JA (1987) Metabolism and turnover of lung surfactant. Am Rev Respir Dis 135:426-444 